\title{
KINEMATIC APPROACH FOR SEISMIC VULNERABILITY ASSESSMENT OF MASONRY CHURCHES
}

\author{
V.CORLITO ${ }^{1}$, G. DE MATTEIS ${ }^{1 *}$ AND P. ROCA $^{2}$ \\ ${ }^{1}$ Department of Architecture and Industrial Design (DADI) \\ University of Campania "Luigi Vanvitelli" \\ San Lorenzo Abbey, 81030 Aversa, Italy \\ e-mails: gianfranco.dematteis@unicampania.it (*corresponding author) \\ valentina.corlito@unicampania.it \\ ${ }^{2}$ Department of Civil and Environmental Engineering \\ Universitat Politècnica de Catalunya \\ (UPC - Barcelona Tech), 08034 Barcelona, Spain \\ e-mail: pere.roca.fabregat@upc.edu
}

Keywords: Vulnerability Assessment; Kinematic Analysis; Masonry Churches; L'Aquila Earthquake

\begin{abstract}
The application of reliable predictive methods for the seismic vulnerability assessment of historical buildings represents a challenging issue in the process of risk mitigation at regional/national scale, in order to undertake appropriate strategies aimed at achieving acceptable safety levels. For the application of such policies, the availability of adequate procedures for the correct evaluation of the seismic risk of specific assets, like churches, is a fundamental topic of investigation. In this paper, a simple procedure based on the linear and non-linear kinematic approach is applied to evaluate the seismic capacity of masonry churches, both in terms of spectral acceleration and spectral displacement. To check the reliability of such a procedure, the obtained results have been compared with the damage scenario observed on a population of churches analysed by the research group in the aftermath of the 2009 L'Aquila earthquake.
\end{abstract}

\section{INTRODUCTION}

Recent seismic events produced extraordinary costs for reconstruction of damaged buildings, showing also a considerable impact on social and cultural factors of the affected territories. In particular, the earthquakes occurred in Italy in the last decades evidenced severe states of damage and significant losses of important historical and architectural assets, emphasising the great fragility of the existing building heritage and stressing the necessity to prevent losses through the definition of reliable preventive protection strategies.

As far as masonry churches are concerned, different methodologies of assessment have been developed, considering various approaches with different levels of investigation [1-4]. The damage probability matrix (DPM) method and the vulnerability index method (VIM) are among the most common vulnerability assessment approaches found in literature $[5,6]$. 
Such methods are mainly based on the observational analyses carried out at territorial scale on churches in the aftermath of significant seismic events (such as Friuli [7], Umbria and Marche [8], Molise [9], L'Aquila [10, 11] and Central Italy [12, 13] earthquakes) which allowed to learn more about the most recurrent damage mechanisms and seismic fragilities of existing churches. Alternative methodologies were also developed on the basis of analytical evaluations, mainly based on the study of macro-element behaviour through linear and non-linear analyses. Different simplified methodologies to derive fragility curves can be found in literature $[14,15]$. With general reference to the approaches used for existing masonry buildings, many studies are definitely worth of being mentioned [16-19].

In this paper a predictive methodology for the seismic vulnerability assessment of masonry churches in large territorial areas is presented, focusing the attention on the three-nave churches of the Abruzzi Region. A simplified procedure, based on the kinematic limit approach, is proposed with the aim to identify the structural capacity of the main detectable macro-elements and to provide predictive tools useful for the development of suitable risk mitigation strategies.

\section{LOCAL RIGID-BLOCK ANALYSIS}

\subsection{Introduction}

masonry building can be considered as an assembly of statically determined elements connected to each other in a unilateral restraint condition. The possible lack of effectiveness (or maybe the absence) of the connections betwee

of the whole structure, event. This statement typological configuratio imply the presence of disconnections, favouring different behaviours
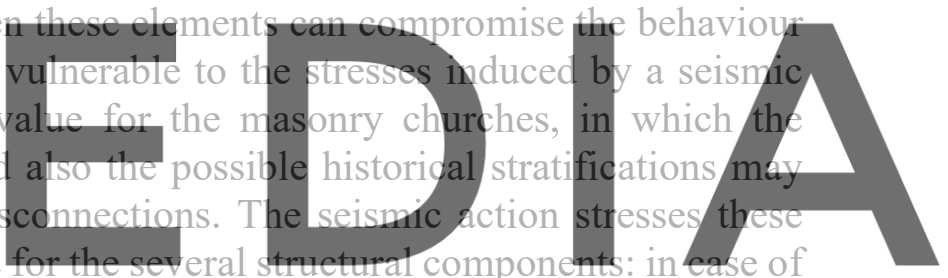
good quality masonry, the damage can occur with the loss of equilibrium of rigid blocks that

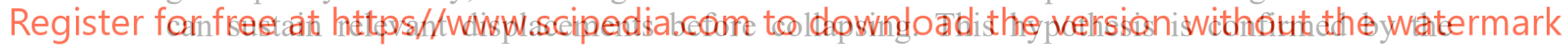
partial collapses observed in the damaged masonry churches after the recent seismic events (Figure 1).

The above observation allows to state that the study of the global seismic response may be less appropriate for many types of historical buildings, for which the use of local models may be more suitable. The analysis of local rigid-body mechanisms [20] considers each structural element composed of a certain number of non-deformable wall blocks, connected to each other and to the rest of construction through internal and external constraints. The set of these constrained rigid blocks must be such as to constitute a kinematic chain with a single degree of freedom (SDOF).

The study of a local mechanism is conducted through the method of limit analysis, following a kinematic approach, according to the following steps: (i) identification of possible collapse mechanisms; (ii) definition of the value of the horizontal load multiplier $\alpha$ involving the activation of the relevant mechanism; (iii) safety check, through the comparison between seismic demand and structural capacity.

More specifically, the structural capacity is evaluated through the linear and non-linear approach, to evaluate the acceleration of the kinematic activation and its ultimate displacement capacity, respectively $[14,21,22]$. 
These criteria can be extended to monumental buildings by recognizing SDOF elements that identify the typical kinematic configurations of macro-elements.
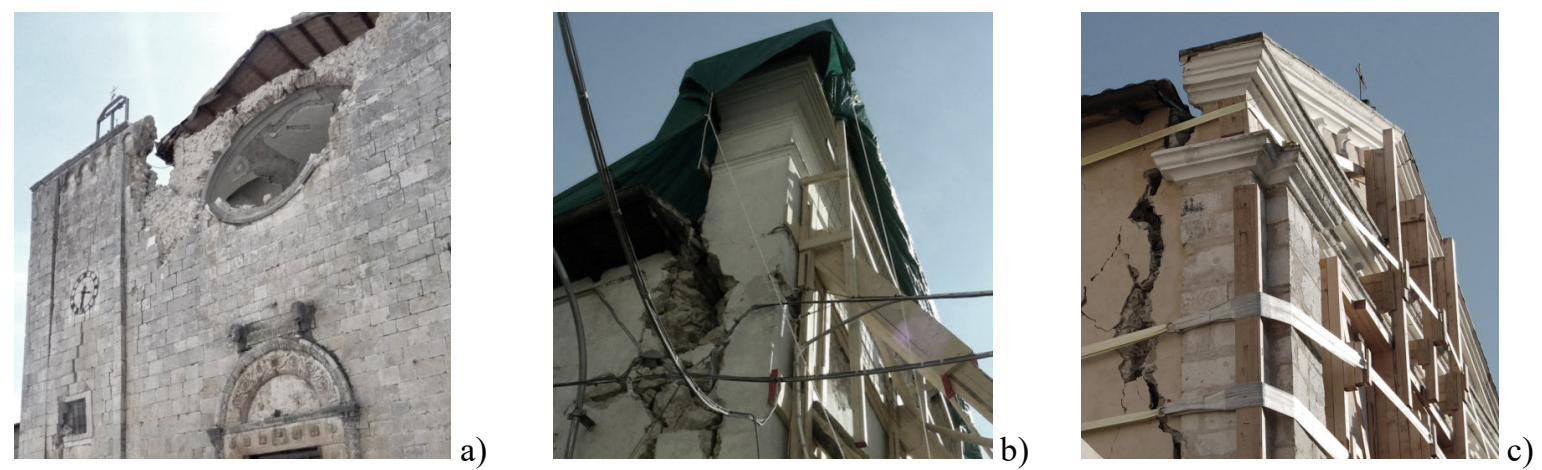

Figure 1: Partial collanses observed in the Italian churches of Sant'Eusanio Martire in Sant'Eusanio Forconese (a), Santa Maria degli Angeli in Paganica (b) and Santa Gemma in Goriano Sicoli (c) (L'Aquila district, Abruzzi).

\subsection{Simplified kinematic procedure}

In this paper, a simplified method for a large-scale vulnerability assessment of churches is considered. The procedure is aimed at identifying the kinematically admissible mechanisms for a population of 64 three-nave shurches located in the territory of L'Aquila [AQ] and SulmonaValva [SU-VA] Dioces accelerations (linear kine analysis). The analysis The analysis of the 1 es (in Abruzzi, Italy)
egards the macro-elem
ocal mechanisms for $n$

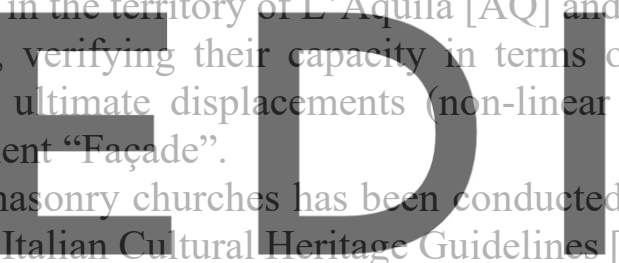
sinematic on the statistical studies carried out in the aftermath of the last Italian seismic events. In

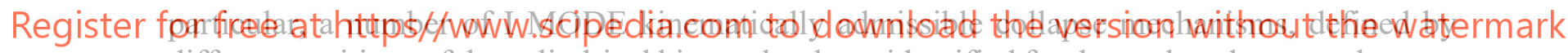
different positions of the cylindrical hinges, has been identified for the analysed macro-element. Then, the analyses have been performed considering the detected constraint conditions, the presence/absence of possible retaining or thrusting elements and the influence of the typological features of the macro-element (Figure 2) on the activation of each possible mechanism, as schematically shown in Figure 3 and in Table 1.

Namely, the identified kinematic motions are:

- global façade monolithic overturning [K1];

- double-skin façade monolithic overturning [K2];

- global façade composed overturning [K3];

- $\quad$ top of the façade monolithic overturning [K4, K5, K6];

- $\quad$ top of the façade composed overturning [K7];

- monolithic vertical bending [K8];

- monolithic vertical bending (external skin) [K9];

- horizontal bending [K10];

- double-skin façade horizontal bending [K11];

- double-skin façade horizontal bending (external skin) [K12]. 

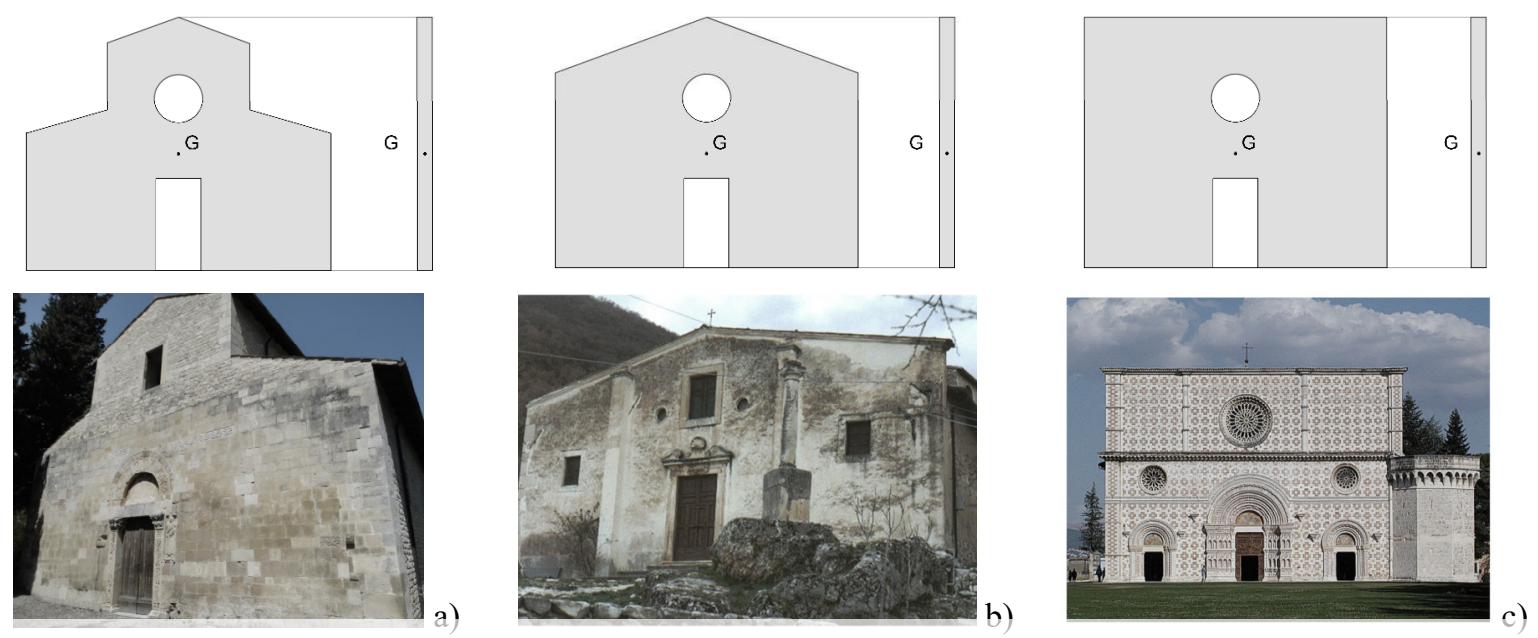

Figure 2: Common type of façades observed in L'Aquila district: salient façade church of San Pietro ad Oratorium in Capestrano (Aq)[SU-VA] (a); gabled façade_church of Sant'Agata in Tussillo (Aq) [AQ] (b); flat façade_church Santa Maria di Collemaggio in L'Aquila [AQ] (c).
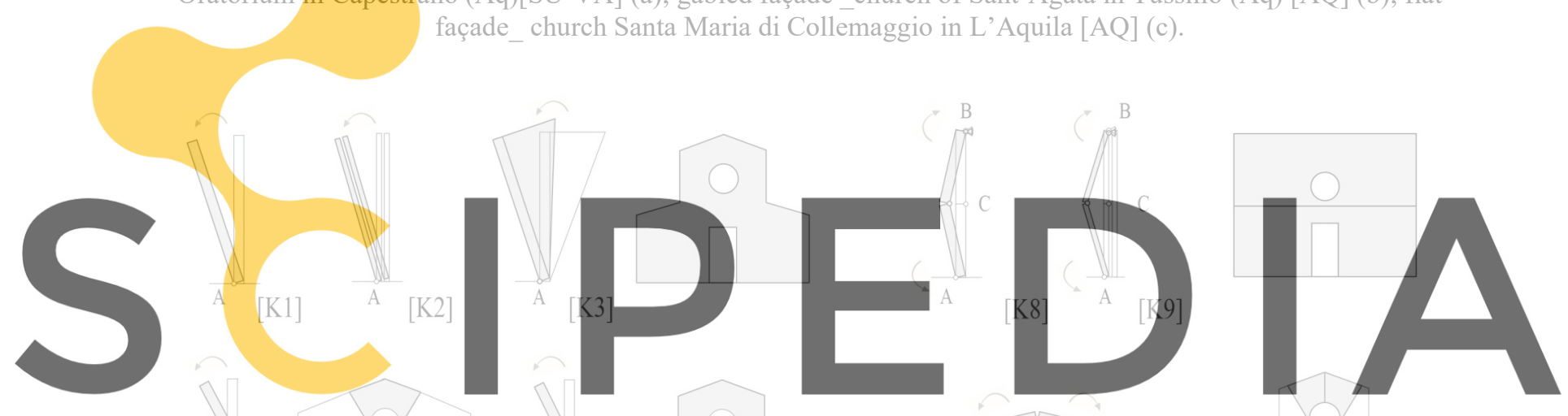

Register for'free at https//www.šcipedia.com to download the vêrsiöil without the watermark

$[\mathrm{K} 4]$

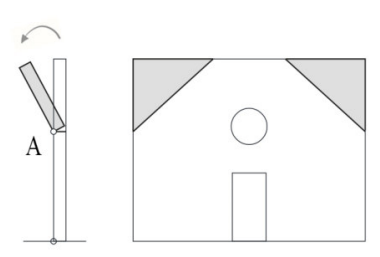

[K6]

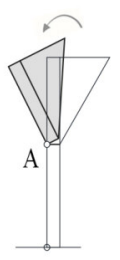

$[\mathrm{K} 5]$

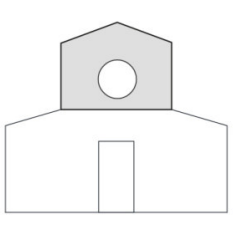

$[\mathrm{K} 7]$

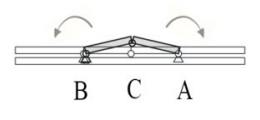

[K11]

[K12]

Figure 3: Possible kinematic motions for the macro-element "Façade".

\section{LINEAR KINEMATIC ANALYSIS}

\subsection{General}

A linear kinematic analysis has been performed for the façades of the considered stock of churches. For each analysed façade and for each identified mechanism, the horizontal load 
Table 1: Influence of typological characteristics and constraint conditions on the identified mechanisms.

\begin{tabular}{|c|c|c|}
\hline Kinematic motion & Façade typology & Constraint conditions \\
\hline$[\mathrm{K} 1]$ & Salient façade & No retaining elements \\
\hline \multirow[t]{2}{*}[\mathrm{K}2]{} & Flat façade & No connections on the top \\
\hline & Gable façade & No connection between transversal walls \\
\hline \multirow[t]{3}{*}[\mathrm{K}3]{} & Salient façade & No retaining elements \\
\hline & Flat façade & No constraints on the top \\
\hline & Gable façade & Connection between transversal walls \\
\hline \multirow[t]{3}{*}[\mathrm{K}4]{} & Salient façade & No constraints on the top \\
\hline & Flat façade & \\
\hline & Gable façade & \\
\hline$[\mathrm{K} 5]$ & Salient façade & No constraints on the top \\
\hline [K6] & Flat façade & No constraints on the top \\
\hline \multirow[t]{2}{*}[\mathrm{K}7]{} & Salient façade & No constraints on the top \\
\hline & & Connection between transversal walls \\
\hline [K8] & Salient façade & Connections on the top \\
\hline [K9] & Flat façade & No connection between transversal walls \\
\hline & Gable façade & \\
\hline$[\mathrm{K} 10]$ & Salient façade & No connections on the top \\
\hline [K11] & Flat façade & Connection between transversal walls \\
\hline [K12] & Gable façade & \\
\hline
\end{tabular}
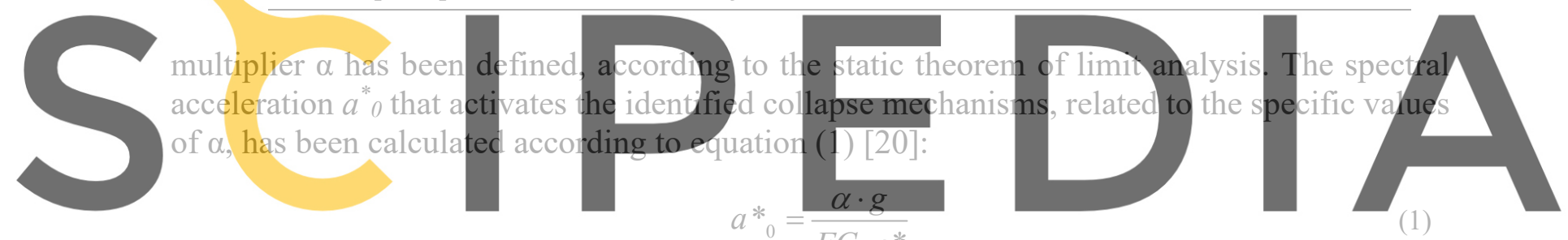

Register for free at hthps/fwwwscipediacigme to downdoad the wersion without the watermark (LC) of the investigated structures (geometry, material, etc.), and $e^{*}$ is the portion of mass participating in the considered mechanism. For the cases being, given the limited knowledge of the characteristics of the structures, $\mathrm{FC}=1.35$ for $\mathrm{LC} 1$ has been assumed.

For the generic mechanism, the safety check for SLV (Life-saving Limit State) is assumed to be satisfied when the spectral acceleration $a^{*}{ }_{0}$ activating the mechanism complies with the structural capacity of the considered macro-element. The evaluation has been based on the definition of the safety index $I_{S, S L V}$, which, for the reference limit state, is obtained as a ratio between the seismic capacity of the structure Cap, $S L V[\mathrm{~g}]$ and the seismic demand Dem, $L V V[\mathrm{~g}]$, according to the standards requirements [20].

The limit value for $I_{S, S L V}$ has been determined according to the Italian Guidelines [22], defining a ratio between the $T_{S L V}$ return period of the seismic action corresponding to the attainment of the SLV Limit state and the corresponding return period $T_{R}$, SLV computed with the equation (2), in relation to the reference period $V_{R}$ and to the probability of exceeding in the reference period $P_{V R}$.

The limit value for the safety index estimated for the considered structures is $I_{S, S L V}=0.614$. 


$$
T_{R}=-\frac{V_{R}}{\ln \left(1-P_{V_{R}}\right)}
$$

\subsection{Application to the investigated churches}

The above linear kinematic analysis with reference to the macro-element "Façade" has been applied to the 64 investigated churches. The relevant results together with a statistical elaboration are given in Table 2, where the following main outcomes are provided:

- $\quad$ the frequency of the collapse mechanisms that the constraint conditions of the structure make kinematically possible (Possible [K]; $\alpha>0$ );

- $\quad$ the frequency of the mechanisms for which the $I_{S, S L V}$ safety index is lower than 1 (Possible [K]; $I_{S, S L V}<1$ );

- $\quad$ the frequency of the mechanisms for which the safety verification in terms of Cap.

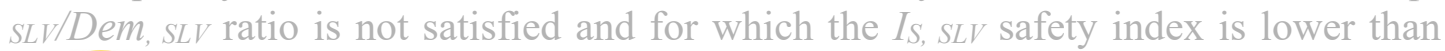
0.614 (Possible [K]; $I_{S, S L V}<0.614$ ).

By the obtained results, it is possible to determine the kinematic motions that cannot be activated (namely [K2], [K9] and [K11]) as well as to identify the probability of activation of the possible kinematics.

The results show that generally there is a high vulnerability of the façades with respect to the kinematic motion [K1] (global façade monolithic overturning), [K4] (top of the façade

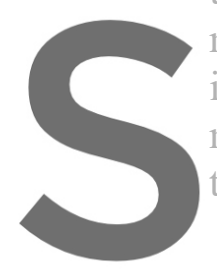
monolithic overturning) indexes are less than mechanisms the values the $13 \%, 7 \%$ and $22 \%$ The performed linea ) and $[K 10]$ (horizontal
of the $I_{S, ~}, L V$ safety do
of the analysed cases.
r kinenatic analysis als
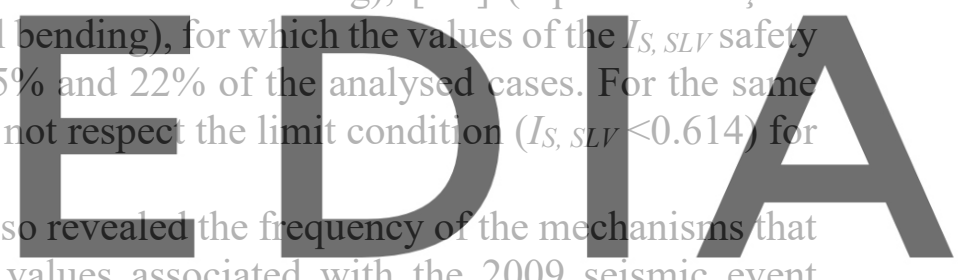

could be potentially activated by the PGA values associated with the 2009 seismic event

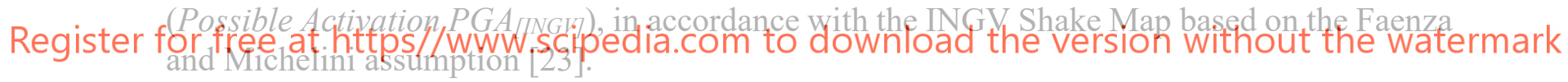

In Table 3, the above results have been also compared with the frequencies of the damage level $d_{k}$ (with $0 \leq d_{k} \leq 5$ ) registered for the analysed churches in the aftermath of the seismic event [24], with refence to the out-of-plane mechanisms of the façade (mechanism [M1]) and of the top of it (mechanism [M2]). In order to check the reliability of the analytical results, the damage level $d_{k}$ corresponding to the activation of the damage mechanism has been considered separately for both values $d_{k}=1$ and $d_{k}=2$, accounting for possible evaluation errors connected to the ambiguous classification of damage.

The comparison shows that for all the kinematic mechanisms related to the whole façade $[\mathrm{K} 1, \mathrm{~K} 3, \mathrm{~K} 8]$ (to be compared with [M1]) and for all those related to the top of the façade [K4, $\mathrm{K} 5, \mathrm{~K} 6, \mathrm{~K} 7, \mathrm{~K} 10, \mathrm{~K} 12]$ (to be compared with [M2]), the frequency of Possible Activation $P G A_{[I N G V]}$ is lower than the activation frequency actually recorded following the seismic event (Observed Activation). Indeed, a better comparison has been obtained with reference to the damage levels $d_{k}>2$, for which more objective criteria in the classification of the damage can be hypothesised.

The correlations between the values of the collapse multiplier $\alpha$ calculated for the Possible $[K](\alpha>0)$ and the damage levels observed for each church for the mechanism [M1] and [M2] 
are shown in Figure 4 and in Figure 5, respectively. As it could be expected, higher values of the collapse multiplier $\alpha$ have been generally obtained for the Possible [K] detected in churches which suffered a lower level of damage $d_{k}$ for the collapse mechanisms [M1] and [M2], stating that the analysed mechanisms has been mainly observed for those churches characterized by lower value of the factor $\alpha$, confirming the validity of the applied analytical procedure.

Table 2: Frequencies of possible kinematic motions for the façades for the 64 analysed churches.

\begin{tabular}{cccccccc}
\hline & $\begin{array}{c}\text { Possible } \\
{[\mathbf{K}]} \\
(\boldsymbol{\alpha}>0)\end{array}$ & $\begin{array}{c}\boldsymbol{\alpha} \\
\text { average } \\
\text { value })\end{array}$ & $\begin{array}{c}\boldsymbol{a}^{*}{ }^{*}[\mathbf{g}] \\
\text { average } \\
\text { value) }\end{array}$ & $\begin{array}{c}\text { Cap, sLv [g] } \\
\text { (average } \\
\text { value) }\end{array}$ & $\begin{array}{c}\text { Dem, suv [g] } \\
\text { (average } \\
\text { value) }\end{array}$ & $\begin{array}{c}\text { Possible [K] } \\
\text { IS, sLv }<1\end{array}$ & $\begin{array}{c}\text { Possible [K] } \\
\text { IS, sLv }<0.614\end{array}$ \\
\hline$[\mathrm{K} 1]$ & $67 \%$ & 0.126 & 0.172 & 0.344 & 0.369 & $48 \%$ & $13 \%$ \\
\hline$[\mathrm{K} 3]$ & $13 \%$ & 0.261 & 0.354 & 0.708 & 0.369 & $10 \%$ & $0 \%$ \\
\hline$[\mathrm{K} 4]$ & $63 \%$ & 0.232 & 0.313 & 0.625 & 0.521 & $25 \%$ & $7 \%$ \\
\hline$[\mathrm{K} 5]$ & $30 \%$ & 0.589 & 0.796 & 1.592 & 0.535 & $0 \%$ & $0 \%$ \\
\hline$[\mathrm{K} 6]$ & $10 \%$ & 0.437 & 0.591 & 1.183 & 0.519 & $5 \%$ & $0 \%$ \\
\hline$[\mathrm{K} 7]$ & $5 \%$ & 0.557 & 0.760 & 1.519 & 0.523 & $0 \%$ & $0 \%$ \\
\hline$[\mathrm{K} 8]$ & $5 \%$ & 0.405 & 0.558 & 1.116 & 0.369 & $0 \%$ & $0 \%$ \\
\hline$[\mathrm{K} 10]$ & $22 \%$ & 0.047 & 0.064 & 0.127 & 0.521 & $22 \%$ & $22 \%$ \\
\hline$[\mathrm{K} 12]$ & $2 \%$ & 0.009 & 0.012 & 0.024 & 0.521 & $2 \%$ & $2 \%$ \\
\hline
\end{tabular}

Table 3: Comparison between the results of the linear kinematic analysis and the frequencies of the $d_{k}$ damage levels registered in the aftermath of the $6^{\text {th }}$ April 2009 earthquake for [M1] and [M2] mechanisms.
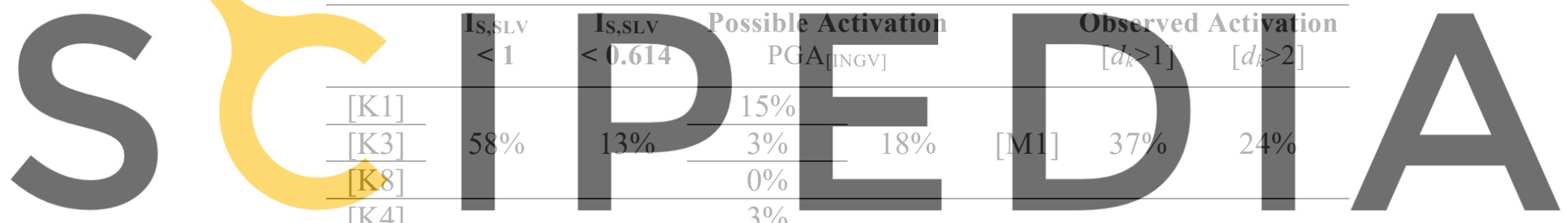

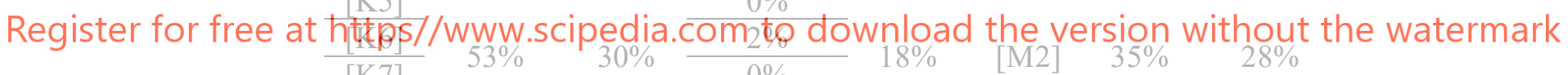
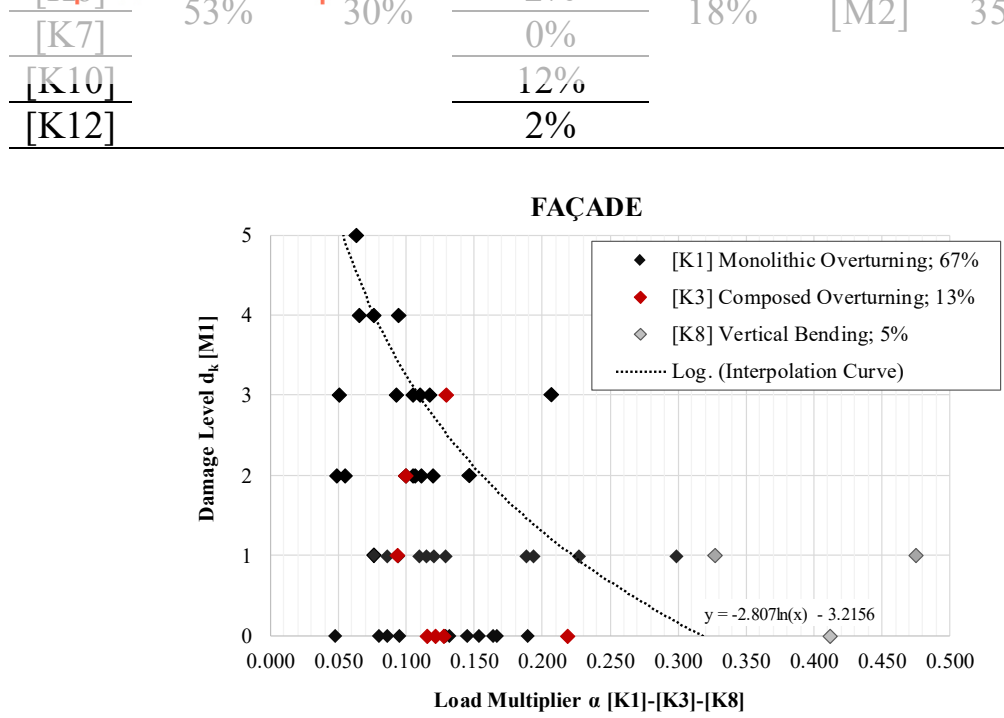

Figure 4: Correlations between the values of the collapse multiplier $\alpha$ calculated for the [K1] [K3] [K8] (with $\alpha>0)$ and the registered damage levels $d_{k}$ for mechanism [M1]. 


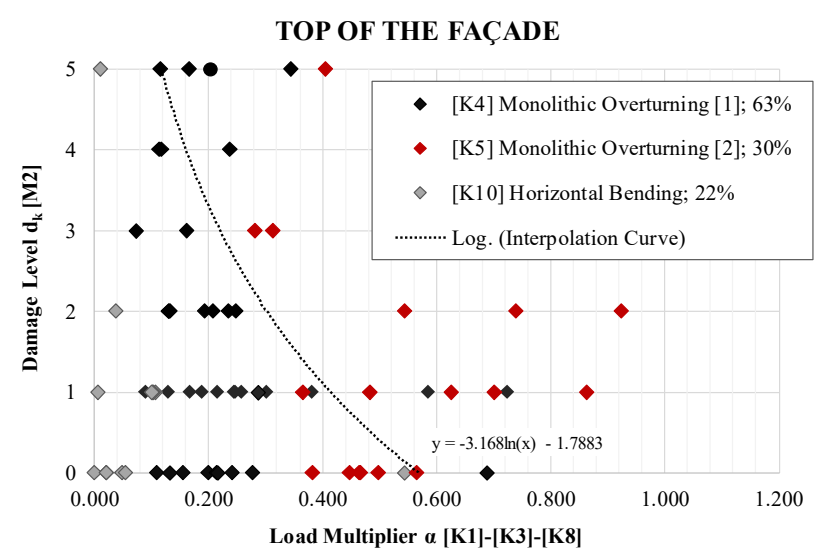

Figure 5: Correlations between the values of the collapse multiplier $\alpha$ calculated for the [K4] [K5] [K10] (with $\alpha>0$ ) and the observed damage levels $d_{k}$ for mechanism [M2].

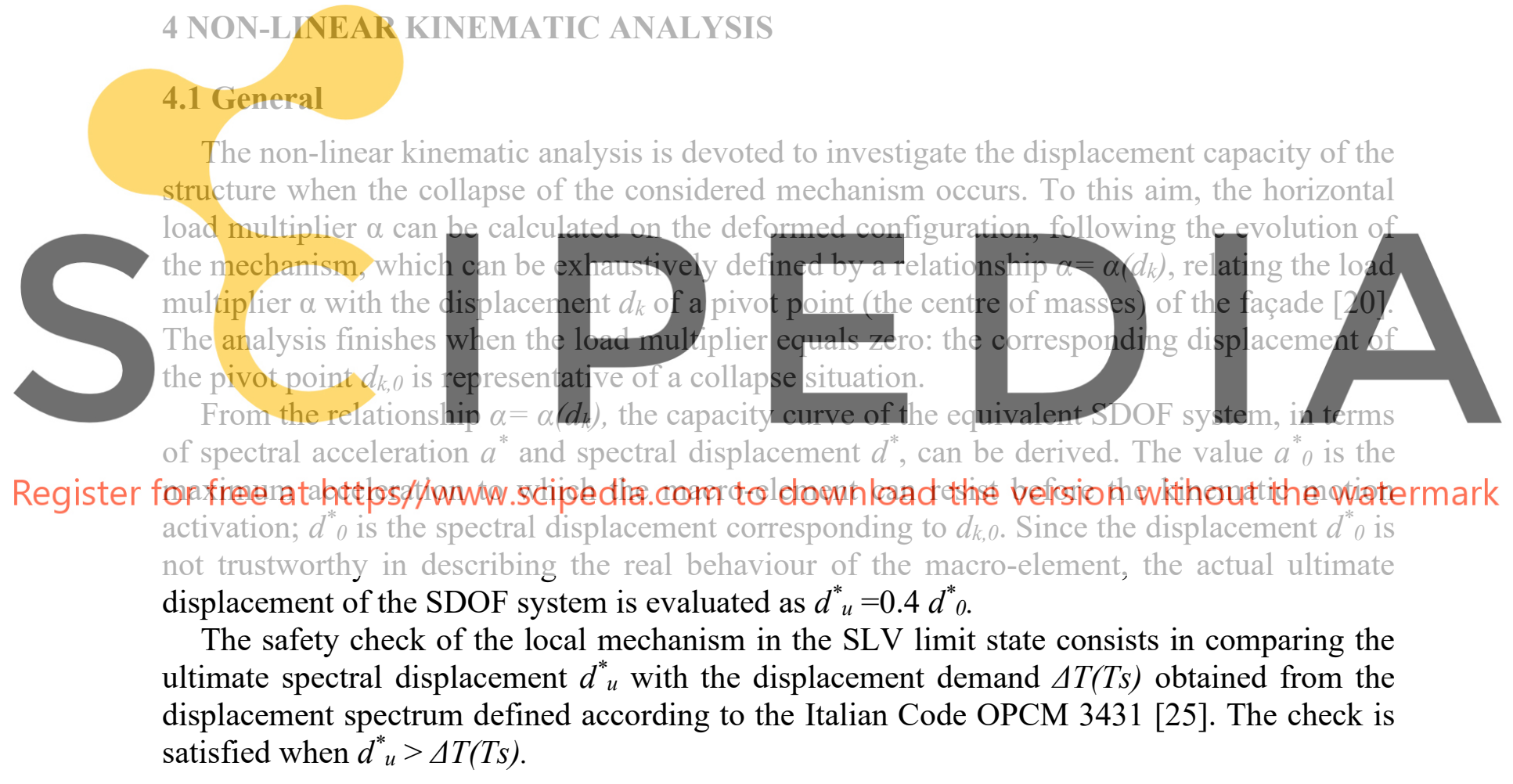

\subsection{Application to the investigated churches}

The non-linear kinematic analysis has been performed for the façade of the 64 analysed churches with reference to the mechanisms for which the safety check in terms of Cap, sLV/Dem, $S L V$ ratio is not satisfied. The check has been carried out considering the displacement demand $\Delta T(T s)$ related to the seismic hazard of the inspected sites.

The results and the corresponding statistical elaboration are given in Table 4 and Table 5; the outcomes reveal a high percentage of Possible Collapse $\left[d^{*}{ }_{u}>\Delta d(T S), s L V\right]$ for the kinematic motions [K4] (top of the façade monolithic overturning). 
The non-linear kinematic analysis also reveals the frequency of the possible collapses occurred through the analysed mechanisms by considering the displacement demand $\Delta T(T S)_{, E}$ induced by the PGA values associated with the 2009 L'Aquila seismic event [INGV] [23].

In Table 6, the results have been compared with the frequencies of the effective collapses (with $d_{k}=5$ ) observed for the out-of-plane mechanisms [M1] and [M2] for the 64 churches following the seismic event [24]. The comparisons shows that, for the kinematic mechanism related to the whole façade [K1] (to be compared with [M1]) and for all those related to the top of the same [K4, K6, K10, K12] (to be compared with [M2]), the frequencies of the possible collapses induced by the PGA values of the seismic event (with $d^{*}{ }_{u}<\Delta d(T S), E$ ) are similar to the percentages of the observed collapses, in particular when the condition Not Verified $[K]-\left(I_{S}\right.$, $S L V<1)$ is considered.

Table 4: Results of the non-linear kinematic analysis. Not Verified [K]-( $\left.\mathrm{I}_{\mathrm{S}, \mathrm{SLV}}<1\right)$.

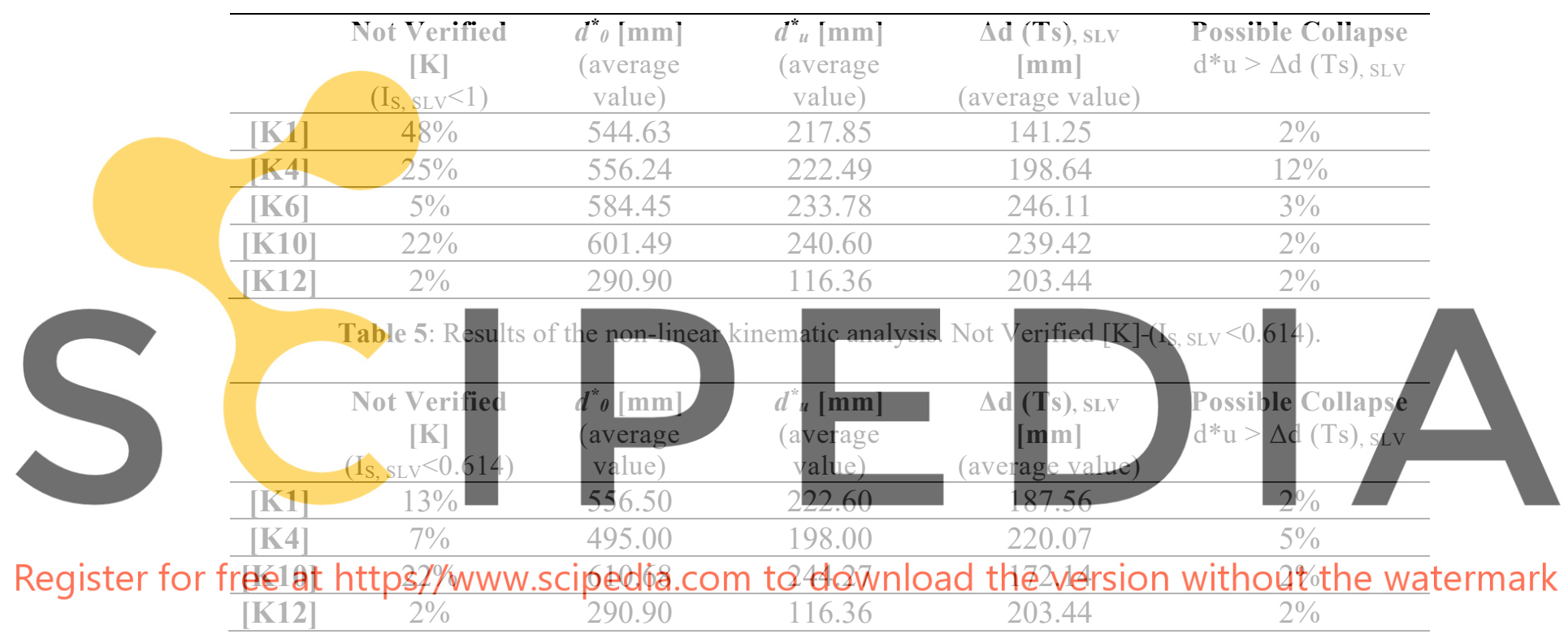

The correlations between the values of the ultimate displacement $d^{*}{ }_{u}$ calculated for the Not Verified $[K] s$ and the damage levels observed in each church for the mechanism [M2] (characterized by a higher percentage of possible activation and collapse compared to [M1]) are shown in Figure $6 \mathrm{a}$ and Figure $6 \mathrm{~b}$ for $\left(I_{S, S L V}<1\right)$ and $\left(I_{S, S L V}<0.614\right)$, respectively.

The obtained output shows that a lower level of damage $d_{k}$ has generally been observed in the cases characterized by a higher structural capacity (in terms of ultimate displacement $d^{*}{ }_{u}$ ); on the contrary, lower value of $d^{*}{ }_{u}$ can be found in churches which experienced partial or total collapses during the 2009 seismic event.

\section{CONCLUSIONS}

In this paper a study related to seismic vulnerability of the facades of existing churches has been carried out. In particular, a kinematic analysis, based on the macro-element approach proposed by the Italian Guidelines, has been applied in order to assess the structural capacity 
Table 6: Comparison between the results of the non-linear kinematic analysis and collapse frequencies $\left(d_{k}=5\right)$ observed after the $6^{\text {th }}$ April 2009 earthquake for [M1] and [M2] mechanisms.

\begin{tabular}{|c|c|c|c|c|c|c|}
\hline \multirow[b]{2}{*}{ [K1] } & \multicolumn{2}{|c|}{$\begin{array}{c}\text { Possible Collapse } \\
\mathrm{d}^{*}{ }_{\mathrm{u}}<\Delta \mathrm{d}(\mathrm{Ts}),{ }_{\mathrm{E}} \\
\left(\mathrm{I}_{\mathrm{S}, \mathrm{SLV}}<1\right)\end{array}$} & \multicolumn{2}{|c|}{$\begin{array}{c}\text { Possible Collapse } \\
\mathrm{d}^{*}{ }_{\mathrm{u}}<\Delta \mathrm{d}(\mathrm{Ts}),{ }_{\mathrm{E}} \\
\left(\mathrm{I}_{\mathrm{S}, \mathrm{SLV}}<0.614\right)\end{array}$} & \multicolumn{2}{|c|}{$\begin{array}{c}\text { Observed Collapses } \\
{\left[\mathrm{d}_{\mathrm{k}}=5\right]}\end{array}$} \\
\hline & $5 \%$ & $5 \%$ & $5 \%$ & $5 \%$ & [M1] & $2 \%$ \\
\hline [K4] & $3 \%$ & \multirow{4}{*}{$8 \%$} & $2 \%$ & \multirow{4}{*}{$5 \%$} & \multirow{4}{*}{ [M2] } & \multirow{4}{*}{$10 \%$} \\
\hline [K6] & $2 \%$ & & - & & & \\
\hline [K10] & $3 \%$ & & $3 \%$ & & & \\
\hline [K12] & $0 \%$ & & $0 \%$ & & & \\
\hline
\end{tabular}
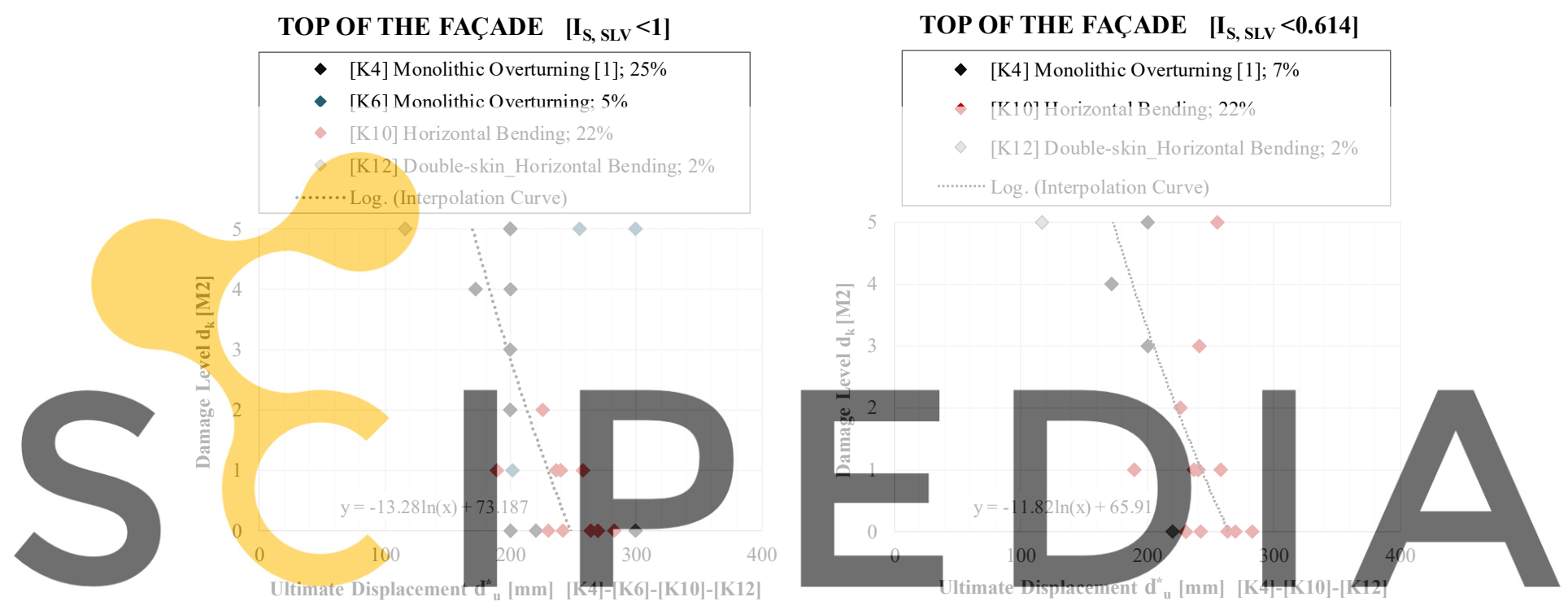

Register for free at https/bwww scipedia,com to download the versign without the watermark the damage levels observed in each church for the mechanism [M2].

of 64 churches that experienced the 2009 L'Aquila earthquake. The analysis and the comparison of the damage levels experienced by the investigated churches allowed the following main outcomes to be outlined:

- the data collected in a territorial scale analysis can be profitably used for the implementation of simplified analytical procedures to be applied on a large-scale approach on homogeneous populations of churches;

- the kinematic approach, based on the identification of the mechanisms kinematically admissible for the analysed churches and the verification of their capacity in terms of resisting accelerations and ultimate displacements, allows to perform an immediate analysis of the structural deficiencies of the examined buildings;

- $\quad$ the applied procedure could allow to avoid, when not necessary, the development of more rigorous and time-consuming analyses, constituting a valid support in the simulation of possible post-earthquake damage scenarios and, consequently, in the definition of adequate preventive strategies for seismic risk mitigation. 


\section{REFERENCES}

[1] Roca, P., Cervera, M., Gariup, G., Pelà, L. Structural Analysis of Masonry Historical Constructions. Classical and Advanced Approaches. Archives of Computational Methods in Engineering (2010). 17: 299-325.

[2] Valente, M., Milani, G. Damage survey, simplified assessment, and advanced seismic analyses of two masonry churches after the 2012 Emilia earthquake. International Journal of Architectural Heritage, (2018), pp 1-24.

[3] Brando, G., Criber, E., De Matteis, G. The effects of L'Aquila earthquake on the St. Gemma church in Goriano Sicoli: part II-fem analysis. Bulletin of earthquake engineering (2015). 13(12): 3733-3748.

[4] Endo, Y., Pelà, L., Roca, P., Da Porto, F., Modena, C. Comparison of seismic analysis methods applied to a historical church struck by 2009 L'Aquila earthquake. Bulletin of Earthquake Engineering (2015). 13: 3749-3778.

[5] Braga, F., Dolce, M., Liberatore, D. A statistical study on damaged buildings and an ensuing review of the MSK-76 scale. Proceedings of the 7th European Conference on Earthquake Engineering (1982). Athens, Greece.

[6] Di Pasquale, G., Orsini, G., Romeo, R.W. New developments in seismic risk assessment in Italy, Bulletin of Earthquake Engineering (2005). 3(1).

[7] Doglioni, F., Moretti, A., Petrini, V. Le chiese e il terremoto - Dalla vulnerabilità constatata nel terremoto del Friuli al miglioramento antisismico nel restauro, verso una politica di prevenzione. Edizioni Lint., Trieste, Italy (1994). (In Italian).

[8] Lagomarsino, S., Podestà, S. Seismic Vulnerability of Ancient Churches: II. Statistical Analysis of Surveyed Data and Methods for Risk Analysis. Earthquake Spectra (2004). 20(2): 395-412.

[9] Lagomarsino, S., Podestà, S. Damage and vulnerability assessment of churches after the 2002 Molise, Italy, earthquake. Earthquake Spectra (2004). 20, Special Issue I, pp. S271S283.

[10] Lagomarsino, S. Damage assessment of churches after L'Aquila earthquake (2009). Bulletin of Earthquake Engineering (2012). 10(1): 73-92.

[11] De Matteis, G, Brando, G, Corlito, V. Predictive model for seismic vulnerability assessment of churches based on the 2009 L'Aquila earthquake. Bulletin of Earthquake Engineering (2019). 17(9): 4909-4936.

[12] Hofer, L., Zampieri, P., Zanini, M. A., Faleschini, F., Pellegrino, C. Seismic damage survey and empirical fragility curves for churches after the August 24, 2016 Central Italy earthquake. Soil Dynamics and Earthquake Engineering, (2018). 111: 98-109.

[13] De Matteis, G, Zizi, M. Seismic Damage Prediction of Masonry Churches by a PGA-Based Approach. International Journal of Architectural Heritage, (2019). 13(7): 1165-1179.

[14] D'Ayala, D. Force and displacement based vulnerability assessment for traditional buildings. Bulletin of Earthquake Engineering (2005). 3(3): 235-265.

[15] Bernardini, A., Gori, R., Modena, C. Application of Coupled Analytical Models and Experiental Knowledge to Seismic Vulnerability Analyses of Masonry Buildings. Earthquake Damage Evaluation and Vulnerability Analysis of Buildings Structures. (1990). 3:161-180. Koridze A (ed), Omega Scientific.

[16] De Matteis, G., Mazzolani, F.M. The Fossanova church: seismic vulnerability assessment 
by numerical and physical testing. International Journal of Architectural Heritage (2010). 4 (3): 222-245.

[17] Milani, G., Lourenco, P. CFE homogenised limit analysis model for masonry structures. Engineering and Computational Mechanics (2011). 164(2): 65-78.

[18] Elyamani, A., Roca, P., Caselles, O., Clapes, J. Seismic safety assessment of historical structures using updated numerical models: The case of Mallorca cathedral in Spain. Engineering Failure Analysis (2017). 74: 54-79.

[19] Roca, P. Studies on the structure of Gothic Cathedrals. Structural Analysis of Historical Constructions (2001), pp.71-90.

[20] Circolare del Ministero delle infrastrutture e dei trasporti 21 gennaio 2019, n. 7 del Consiglio superiore del Lavori Pubblici recante "Istruzioni per l'applicazione dell'Aggiornamento delle "Norme tecniche per le costruzioni" di cui al decreto ministeriale 17 gennaio 2018". (In Italian).

[21] Doherty, K., Griffith, M.C., Lam, N., Wilson, J. Displacement-based seismic analysis for out-of-plane bending of unreinforced masonry walls. Earthquake Engineering \& Structural Dynamics (2002). 31: 833 - 850.

[22] Minister of Heritage and Cultural Activities, Circular n.26, Italian Code for protection of cultural heritage. "Linee Guida per la valutazione e la riduzione del rischio Sismico del patrimonio culturale con riferimento alle norme tecniche per le costruzioni". Prot 10953 of 02/12/2010 (updated to 2011). (In Italian).

Faenza, L., Michelini, A. Regression analysis of MCS intensity and ground motion spectral accelerations (SAs) in Italy, Geophysical Journal International (2011). 186(3): 14151430.

[23] Grunthal, G. European Macroseismic Scale. Vol. 15 (1998). Centre Européen de Géodynamique et de Séismologie, Luxembourg.

[24] O.P.C.M. 3 maggio 2005, n. 3431 (1). Ulteriori modifiche ed integrazioni all'O.P.C.M. 20 marzo 2003 n. 3274, recante «Primi elementi in materia di criteri generali per la classificazione sismica del territorio nazionale e di normative tecniche per le costruzioni in zona sismica». Gazz. Uff. 10 maggio 2005, n. 107, S.O (In Italian). 